\title{
Biosynthesis of the proteasome inhibitor syringolin A: the ureido group joining two amino acids originates from bicarbonate Christina Ramel ${ }^{1}$, Micha Tobler ${ }^{1}$, Martin Meyer ${ }^{1}$, Laurent Bigler ${ }^{2}$, Marc- Olivier Ebert ${ }^{3}$, Barbara Schellenberg ${ }^{1}$ and Robert Dudler*1
}

\author{
Address: ${ }^{1}$ Institute of Plant Biology and Zurich-Basel Plant Science Center, University of Zurich, Zurich, Switzerland, ${ }^{2}$ Institute of Organic \\ Chemistry, University of Zurich, Zurich, Switzerland and ${ }^{3}$ Laboratory of Organic Chemistry, ETH Zurich, Zurich, Switzerland \\ Email: Christina Ramel - cramel@botinst.uzh.ch; Micha Tobler - micha.tobler@glycovaxyn.com; Martin Meyer - martin.d.meyer@gmail.com; \\ Laurent Bigler - lbigler@oci.uzh.ch; Marc-Olivier Ebert - ebert@org.chem.ethz.ch; Barbara Schellenberg - bschellenberg@botinst.uzh.ch; \\ Robert Dudler* - rdudler@botinst.uzh.ch \\ * Corresponding author
}

Published: 28 October 2009

BMC Biochemistry 2009, 10:26 doi:10.1 |86/|47|-209|-10-26

Received: 21 August 2009

Accepted: 28 October 2009

This article is available from: http://www.biomedcentral.com/|47|-209|//0/26

(c) 2009 Ramel et al; licensee BioMed Central Ltd.

This is an Open Access article distributed under the terms of the Creative Commons Attribution License (http://creativecommons.org/licenses/by/2.0), which permits unrestricted use, distribution, and reproduction in any medium, provided the original work is properly cited.

\begin{abstract}
Background: Syringolin A, an important virulence factor in the interaction of the phytopathogenic bacterium Pseudomonas syringae pv. syringae B728a with its host plant Phaseolus vulgaris (bean), was recently shown to irreversibly inhibit eukaryotic proteasomes by a novel mechanism. Syringolin $A$ is synthesized by a mixed non-ribosomal peptide synthetase/polyketide synthetase and consists of a tripeptide part including a twelve-membered ring with an $\mathrm{N}$-terminal valine that is joined to a second valine via a very unusual ureido group. Analysis of sequence and architecture of the syringolin $A$ synthetase gene cluster with the five open reading frames sylA-sylE allowed to formulate a biosynthesis model that explained all structural features of the tripeptide part of syringolin $A$ but left the biosynthesis of the unusual ureido group unaccounted for.

Results: We have cloned a $22 \mathrm{~kb}$ genomic fragment containing the sylA-sylE gene cluster but no other complete gene into the broad host range cosmid pLAFR3. Transfer of the recombinant cosmid into Pseudomonas putida and $P$. syringae pv. syringae SM was sufficient to direct the biosynthesis of bona fide syringolin $A$ in these heterologous organisms whose genomes do not contain homologous genes. NMR analysis of syringolin $A$ isolated from cultures grown in the presence of $\mathrm{NaH}^{13} \mathrm{CO}_{3}$ revealed preferential ${ }^{13} \mathrm{C}$-labeling at the ureido carbonyl position.

Conclusion: The results show that no additional syringolin A-specific genes were needed for the biosynthesis of the enigmatic ureido group joining two amino acids. They reveal the source of the ureido carbonyl group to be bicarbonate/carbon dioxide, which we hypothesize is incorporated by carbamylation of valine mediated by the sylC gene product(s). A similar mechanism may also play a role in the biosynthesis of other ureido-group-containing NRPS products known largely from cyanobacteria.
\end{abstract}

\section{Background}

Syringolins are a family of closely related cyclic peptide derivatives that are secreted by many strains of the phy- topathogenic bacterium Pseudomonas syringae pv. syringae (Pss) in planta and under certain culture conditions $[1,2]$. Syringolin A, the major variant, was shown not only to 
induce acquired resistance in rice and wheat after spray application, but also to trigger hypersensitive cell death at infection sites of wheat and Arabidopsis plants infected by compatible powdery mildew fungi $[3,4]$. Recently, syringolin A was shown to be an important virulence factor in the interaction of Pss B728a with its host plant Phaseolus vulgaris (bean), and its cellular target has been identified. Syringolin A irreversibly inhibits the eukaryotic proteasome by a novel mechanism, representing a new structural class of proteasome inhibitors $[5,6]$.

Structure elucidation revealed that syringolin A is a tripeptide derivative consisting of an $\mathrm{N}$-terminal valine followed by the two non-proteinogenic amino acids 3,4-dehydrolysine and 5-methyl-4-amino-2-hexenoic acid, the latter two forming a twelve-membered macrolactam ring. The $\mathrm{N}$-terminal valine is in turn linked to a second valine via an unusual ureido group (Figure $1 \mathrm{~A} ;[1]$ ). The minor variants syringolin $\mathrm{B}$ to syringolin $\mathrm{F}$ differ from syringolin A by the substitution of one or both valines with isoleucine residues, by the substitution of 3,4-dehydrolysine with lysine, and by combinations thereof [2]. The structure of syringolin A suggested that it was synthesized by a nonribosomal peptide synthetase (NRPS), large modular enzymes that activate and condense amino acids according to the thiotemplate mechanism (for reviews see e.g. [7-9]). We previously cloned and delimited by mutational analysis a genomic region from Pss B301D-R containing five open reading frames ( $s y l A-s y l E)$ necessary for syringolin biosynthesis (Figure $1 \mathrm{~B} ;[10])$. Whereas sylA and syle encode a putative transcription activator and an exporter, respectively, sylC encodes a typical NRPS module predicted to activate valine, whereas sylD codes for two additional NRPS modules (of which the first is predicted to activate lysine and the second is predicted to activate valine [10]) and a type I polyketide synthetase (PKS) module. Type I PKS are also modular enzymes that, similar to fatty acid synthesis, extend a starter molecule by condensation/decarboxylation of malonate extender units (for reviews see e.g. $[11,12]$ ). The analysis of the structure and architecture of the syl gene cluster led to the postulation of a model that completely accounts for the biosynthesis of the tripeptide part of syringolin A, including its ring structure with the 5-methyl-4-amino-2-hexenoic acid and the 3,4-dehydrolysine (Figure 1C, [10]). However, although the addition of the ureido group and its attached second valine could not be explained by the model, the syl gene cluster did not contain additional open reading frames, which, if present, could potentially have been involved in the biosynthesis of this unexplained part.

Here we show that the genes sylA-sylE are sufficient to direct the biosynthesis of bona fide syringolin A when heterologously expressed in Pseudomonas putida and Pss SM, two organisms which do not produce syringolin A and have no syl gene cluster homolog in their genomes. Thus, biosynthesis of the ureido group with its attached terminal valine is achieved without additional syringolin A-specific genes $(i . e$. genes with no other function than in syringolin A biosynthesis). We hypothesized that biosynthesis of the ureido group would most likely be accomplished by the product of the sylC gene, which would, in addition to the extracyclic peptidyl valine, also activate the terminal valine and join the two residues by incorporation of a carbonyl group derived from hydrogen carbonate/carbon dioxide, thus forming the ureido moiety. We demonstrate by NMR spectroscopic analysis of syringolin A isolated from Pss cultures grown in the presence of $\mathrm{NaH}^{13} \mathrm{CO}_{3}$ that the ${ }^{13} \mathrm{C}$ isotope is preferentially found at the position of the ureido carbonyl atom. These results support our hypothesis, which may be of relevance for the hitherto unknown biosynthesis of other ureido-groupcontaining NRPS products largely known to be produced by cyanobacteria [13-20].

\section{Results}

\section{Biosynthesis of syringolin $A$ in heterologous organisms}

In order to test whether the sylA-sylE gene cluster was sufficient to direct syringolin A biosynthesis, we constructed a cosmid containing the sylA-sylE genes but no other complete gene by taking advantage of AscI and NotI restriction sites flanking the syl gene cluster (Figure 1B). Southern blot analysis of AscI/NotI-digested genomic DNA of Pss B301D-R probed with a syla gene fragment labeled the expected $22 \mathrm{~kb}$ fragment and thus confirmed the uniqueness of the restriction sites in the relevant genome region (data not shown). Thus, Pss B301D-R genomic DNA digested with AscI and NotI was separated by agarose gel electrophoresis. Fragments in the $20-23 \mathrm{~kb}$ size range were eluted and cloned into the wide host range cosmid pLAFR3 [21]. After packaging into lambda phages and transfection into E. coli XL-1Blue, the library was screened with a radiolabeled sylA gene probe. Positive clones were isolated and confirmed to contain the complete syl gene cluster by PCR amplification and sequencing of the expected insert ends. One of the confirmed clones was designated pPL3syl and chosen for further work.

To test the functionality of pPL3syl, the markerless Pss B301D-R mutant $\Delta$ syl was constructed in which the complete syl gene cluster was deleted. The pPL3syl cosmid was then mobilized into the $\Delta$ syl deletion mutant by triparental mating. We previously showed that infiltration of syringolin A-producing Pss strains or isolated syringolin A into rice leaves leads to the accumulation of transcripts corresponding to the defense-related Pir $7 b$ gene (encoding an esterase; [22]), whereas strains or mutants unable to synthesize syringolin A do not activate this gene $[1,23]$. Syringolin A was originally identified and isolated based 
A<smiles>CC(=O)NCC/C=C/[C@H](NC(C)(C)C(=O)[C@H](NC(C)=O)C(C)C)C(=O)N[C@@H](C(=O)O)C(C)C</smiles>

B

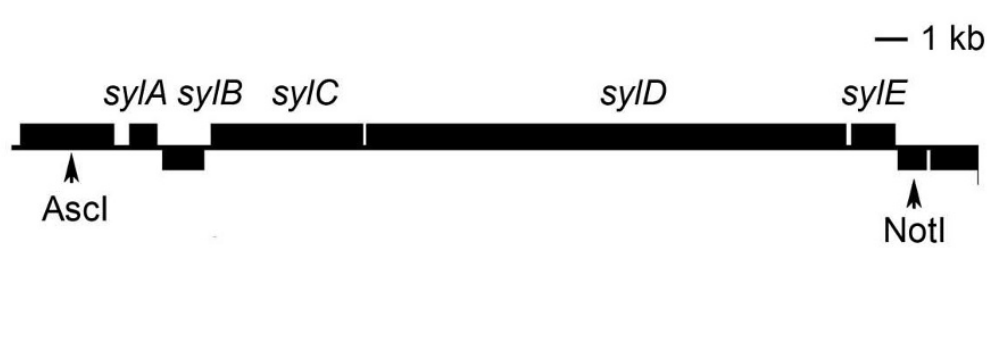

5-Methyl-4-amino-hexenoic acid

C

SylD

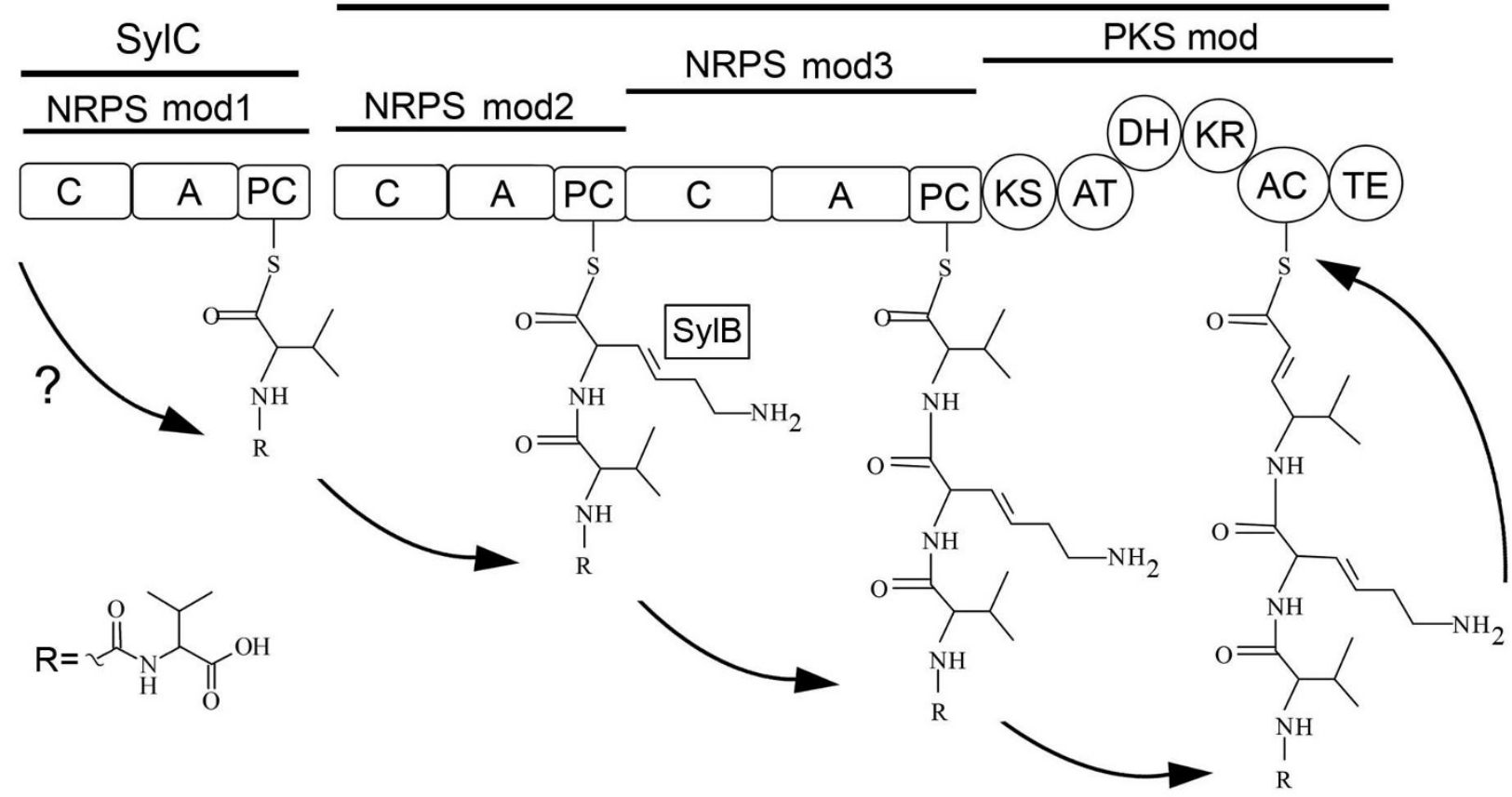

Figure I

Structure and biosynthesis model of syringolin A. A. Structure of syringolin A. Amino acid constituents are delimited by bars. Val, valine. B. Genomic region of Pss B30ID-R containing the sylA-sylE genes. Boxes above and below the line denote ORFs on the top and the bottom strand, respectively. Arrows indicate restriction sites used for cloning of the gene cluster into the cosmid pPL3syl. The sylA, sylB, and sylE genes encode a LuxR-type transcription activator, a rhizobitoxin desaturase-like protein thought to desaturate the lysine residue, and an efflux transporter, respectively [10]. The sylC gene encodes an NRPS module, while sylD codes for two NRPS modules and one PKS module [10] C. Biosynthesis model of the tripeptide part of syringolin $A$. The open boxes represent domains in modules of the syringolin $A$ synthetase labeled with $C$, condensation domain; A, adenylation domain; PC, peptide carrier protein; KS, ketoacyl synthase; AT, acyl transferase; DH, dehydratase; KR, ketoreductase; AC, acyl carrier protein; TE, thioesterase. The A domains of the NRPS modules are thought to activate valine (NRPS modI), lysine (NRPS mod2), and valine (NRPS mod3) [10]. The question mark indicates the unexplained synthesis and attachment of this group. The figures are adapted from [10].

on its action on the Pir7b gene in rice [1]. We thus infiltrated the B301D-R wild-type strain, the syringolin-negative mutants $\Delta$ syl and sylA_KO (contains a plasmid insertion interrupting the sylA transcription activator gene [10]), as well as $\Delta$ syl (pPL3syl), the deletion mutant com- plemented with pPL3syl, into rice leaves. RNA was extracted and subjected to gel blot analysis with regard to Pir $7 b$ transcript accumulation. As expected and in contrast to the wild type, the syringolin A-negative mutants did not induce Pir7b transcript accumulation, whereas the dele- 
A

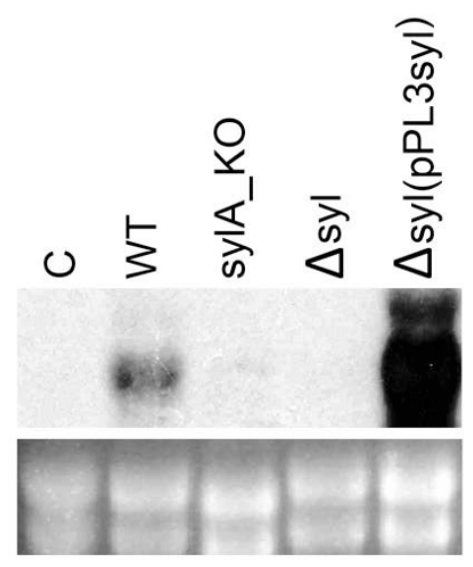

B $26 \mathrm{~h}$

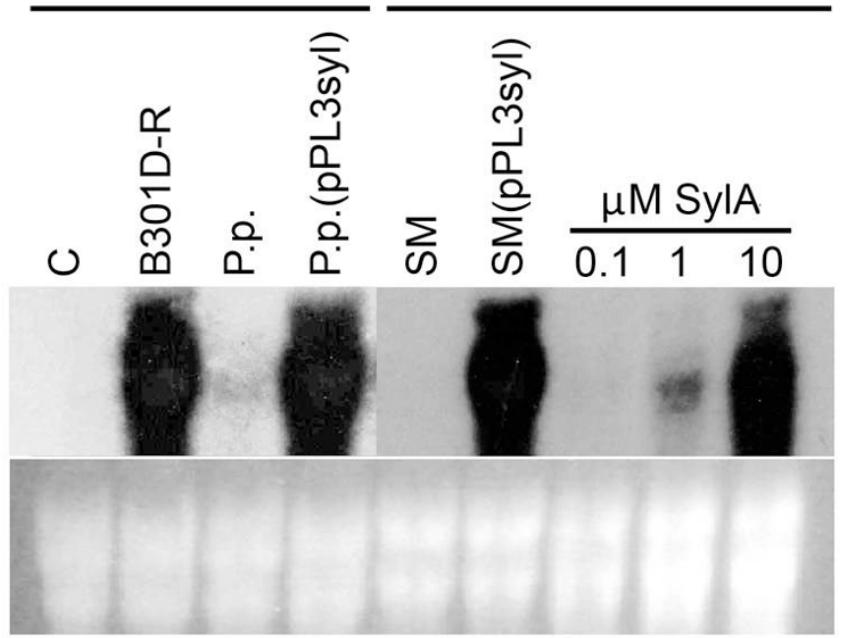

Figure 2

Gel blot analysis of Pir7b transcript accumulation. A. RNA was extracted from rice leaves infiltrated with water (C), Pss B30ID-R (WT), a sylA plasmid insertion mutant (sylA_KO), a syl cluster deletion mutant ( $\Delta$ syl), and $\Delta$ syl (pPL3syl), the deletion mutant complemented with the wildtype syl gene cluster. Top panel, autoradiogram (exposed for $5 \mathrm{~h}$ ); bottom panel, ethidium bromide (EtBr)-stained agarose gel. B. Lanes were loaded with RNA extracted from rice leaves infiltrated as indicated. C, water control; B30ID-R, Pss wild-type strain; P.p, P. putida P3; P.p. (pPL3syl), P. putida P3 transformed with the syl gene cluster; SM, Pss SM; SM (pPL3syl); Pss SM transformed with PPL3syl, and syringolin A solutions of the indicated concentrations. Top panel, autoradiogram (exposure times indicated on top), bottom panel, EtBr-stained gel.

tion mutant complemented with the pPL3syl cosmid led to a much stronger induction of the Pir $7 b$ gene (Figure 2A). This strongly suggested that pPL3syl contained a functional syl gene cluster able to direct syringolin A synthesis in the $\Delta$ syl deletion mutant. This does not exclude the possibility that genes not present in the syl gene cluster are necessary for syringolin A production because such genes would also be present in the $\Delta$ syl mutant background.

Next we wanted to mobilize pPL3syl into Pseudomonas strains not carrying syl gene homologs and lacking syringolin A production as evidenced by PCR, DNA gel blot analysis of genomic DNA, high performance liquid chromatography (HPLC) analysis of culture supernatants with regard to syringolin A content, infiltration into rice leaves followed by monitoring of Pir $7 b$ transcript accumulation, and whole genome sequence comparisons where possible (data not shown). After repeated unsuccessful attempts to transfer pPL3syl into the P. syringae pv. tomato DC3000 strain (all tetracycline-resistant putative transformants analyzed contained deletion variants of pPL3syl), the cosmid was successfully transferred into the non-pathogenic bacterium P. putida P3 [24] and Pss SM, a strain originally isolated from wheat $[23,25]$. Gel blot analysis of RNA extracted from rice leaves infiltrated with parental and transformed strains showed that, as expected, P. putida P3 and Pss SM did not induce Pir $7 b$ transcript accumulation. In contrast, both strains lead to Pir7b gene induction when carrying the pPL3syl cosmid (Figure 2B), suggesting that pPL3syl conferred the ability for syringolin A biosynthesis to these strains.

To confirm this, the transformed strains were grown in shaken cultures in $\mathrm{SRM}_{\mathrm{AF}}$ medium and conditioned media were analyzed by HPLC. As shown in Figure 3, both strains produced a compound eluting at $15.5 \mathrm{~min}$, the elution time of the syringolin A standard. Peaks were collected from multiple HPLC runs and subjected to mass

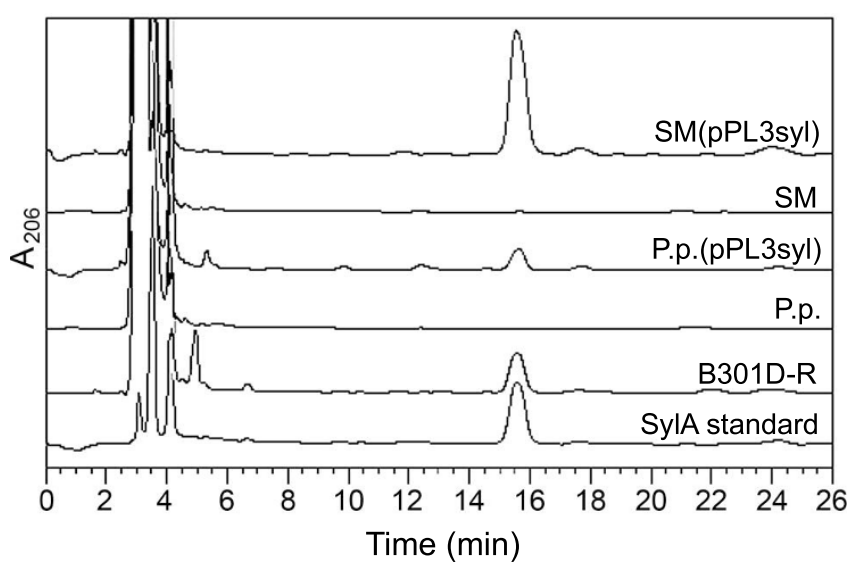

\section{Figure 3}

HPLC analysis of syringolin A content in conditioned $\mathbf{S R M}_{\mathbf{A F}}$ media. Conditioned media were sterile-filtrated and $20-\mu \mathrm{l}$-aliquots were loaded on the column. Absorption was monitored at $206 \mathrm{~nm}$. Labels of HPLC traces are the same as in the legend to Figure 2B. 
spectrometry. HPLC-high resolution-electrospray ionization-mass spectrometry (HPLC-HR-ESI-MS) of the peaks from Pss SM and P. putida P3 carrying pPL3syl, and the Pss B301D-R wild type showed quasi-molecular ions $[\mathrm{M}+\mathrm{H}]^{+}$ at $m / z 494.29808$ (1.5 ppm difference from calculated exact mass), 494.29653 (1.1 ppm), and 494.29799 (1.4 ppm), respectively, matching the empirical formula $\mathrm{C}_{24} \mathrm{H}_{40} \mathrm{~N}_{5} \mathrm{O}_{6}{ }^{+}$(protonated adduct of syringolin A; calculated exact mass 494.29731). We conclude from these experiments that the syl genes contained in pPL3syl are sufficient to direct syringolin A biosynthesis in these heterologous strains and no further syringolin A-specific genes, i.e. genes that exclusively function in syringolin A biosynthesis, are necessary.

\section{The ureido carbonyl group of syringolin $A$ is incorporated from bicarbonate/carbon dioxide}

The above results raised the question of how the ureidovaline is synthesized and incorporated into syringolin A. We hypothesized that this would most likely be accomplished by the product of the sylC gene, which would, in addition to the $\mathrm{N}$-terminal valine of the tripeptide part of syringolin A, also activate the second valine and join the two residues via their amino groups formally by amidation of carbonic acid, thus forming the ureido moiety. If true, feeding syringolin A-producing cultures with ${ }^{13} \mathrm{C}$ labeled hydrogen carbonate should result in syringolin A that is preferentially labeled with ${ }^{13} \mathrm{C}$ at the ureido carbonyl position. Thus, Pss B301D-R transformed with pOEAC, a plasmid carrying the sylA transcriptional activator gene under the control of the lac $Z$ promoter, was grown in $\mathrm{SRM}_{\mathrm{AF}}$ medium. After $48 \mathrm{~h},{ }^{13} \mathrm{C}$-labeled sodium hydrogen carbonate was added to a final concentration of $70 \mathrm{mM}$ and the culture was further grown for $20 \mathrm{~h}$. Syringolin A was isolated from conditioned medium as described [4] and subjected to ${ }^{13} \mathrm{C}$ NMR analysis.

The spectrum of labeled syringolin A was normalized in order to get the same signal intensities for the valine methyl groups as in the unlabeled sample. Comparison of the normalized NMR spectra revealed that the signal from the ureido carbon atom in ${ }^{13} \mathrm{C}$-labeled syringolin $\mathrm{A}$ was 45-fold stronger than the corresponding signal from unlabeled syringolin A (Figure 4). Inspection of the resolved ${ }^{13} \mathrm{C}$ satellite of the valine methyl group at lowest field in the ${ }^{1} \mathrm{H}$ spectrum of labeled syringolin A (data not shown) suggests a ${ }^{13} \mathrm{C}$ content close to natural abundance. Therefore, the 45-fold signal enhancement in labeled syringolin A directly corresponds to the absolute ${ }^{13} \mathrm{C}$ enrichment at this site. The normalized signal strengths of all other $\mathrm{C}$ atoms were equal in labeled and unlabeled syringolin $\mathrm{A}$, with the exception of the $\mathrm{C} 4$ position of 3,4-dehydrolysine, whose signal was enhanced approximately 16-fold in ${ }^{13} \mathrm{C}$-labeled syringolin A (Figure 4A, B). Inspection of biosynthetic pathways using the KEGG database [26] revealed that this can be attributed to a carboxylation reaction in the biosynthesis of lysine. The C4 atom of lysine represents the $\mathrm{C} 4$ atom of L-aspartate-4-semialdehyde, a derivative of aspartate, which is condensed to pyruvate to yield the intermediary compound L-2,3-dihydrodipicolinate in bacterial lysine biosynthesis. The $\mathrm{C} 4$ atom of aspartate in turn originates from the carboxylation of pyruvate to oxaloacetate, an intermediary compound in the tricarboxylic acid cycle, which is transaminated to aspartate. Thus, enhanced ${ }^{13} \mathrm{C}$-labeling of lysine with $\mathrm{H}^{13} \mathrm{CO}_{3}{ }^{-}$at the $\mathrm{C} 4$ position is to be expected. We note that malonate will also be labeled by $\mathrm{H}^{13} \mathrm{CO}_{3}{ }^{-}$as it is derived from acetate by carboxylation. However, the label will be removed by the condensation/decarboxylation of malonate to the peptide chain during syringolin A biosynthesis. We conclude from this analysis that our hypothesis is correct, i.e. that the ureido carbonyl moiety in syringolin A originates from the incorporation of hydrogen carbonate/carbon dioxide.

\section{Discussion}

We have demonstrated that the syl gene cluster is sufficient to direct syringolin A synthesis in heterologous organisms. Although the biosynthesis model presented earlier [10] plausibly explained every structural feature of the syringolin A tripeptide part through the enzymatic actions of the $s y l B, s y l C$, and $s y l D$ gene products, the generation and condensation of the ureido valine remained enigmatic. As the other genes present in the syl cluster encode a transcriptional activator ( $s y l A$ gene) and an exporter ( $s y l E$ gene), a plausible hypothesis was that the $s y l C$ encoded NRPS module not only activated the N-terminal peptidyl valine, but also the ureido valine, and that the ureido carbonyl moiety is incorporated from hydrogen carbonate/carbon dioxide. As shown above, in vivo labeling of syringolin A with ${ }^{13} \mathrm{C}$-hydrogen carbonate supports this hypothesis. Currently, we can only speculate how this is achieved. One possibility is that the quaternary syringolin A synthetase complex may contain two (not necessarily identical) molecules derived from the sylC gene per SylD polypeptide. Both $s y l C$ gene products would activate valine, or, to a certain degree, isoleucine in minor syringolin variants [2]. The first valine would then be carbamylated by $\mathrm{HCO}_{3}-/ \mathrm{CO}_{2}$, perhaps without the action of another enzyme, as has been reported for the carbamylation of a catalytic lysine residue in $\beta$-lactamases of class D $[27,28]$. The ureido moiety would then be formed by amide bond formation between the carbamylated valine and the second valine. In this scenario, it remains unclear how the first valine, which, like the second one, is envisioned to be bound to the peptide carrier protein domain by a thioester bond, is released upon ureido bond formation. It is also conceivable that ureido bond formation is achieved by a single SylC protein, which contains a condensation domain usually absent from starter modules 


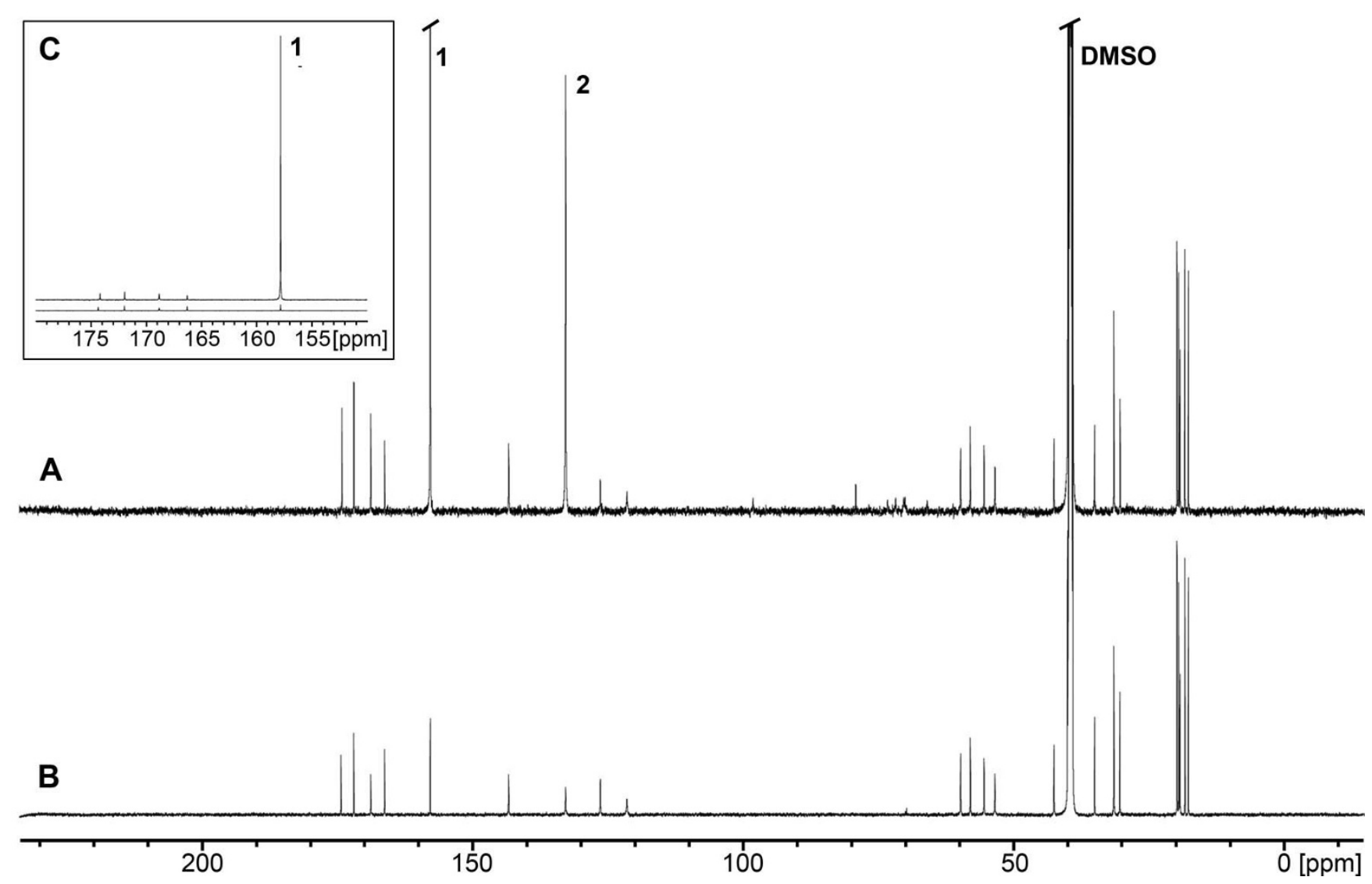

Figure 4

13 C-NMR spectra of in vivo $\mathrm{NaH}^{13} \mathrm{CO}_{3}$-labeled and unlabeled syringolin $\mathrm{A}$. The spectra of $\mathrm{NaH}^{13} \mathrm{CO}_{3}$-labeled $(\mathrm{A})$ and unlabeled (B) syringolin A have been scaled to give equal signal intensities for the methyl groups of the valine residues (I7.4, I7.5, 19.0, and 19.I ppm shifts). The signals at I57.8 ppm (marked I; clipped off) and I32.8 ppm (marked 2) correspond to the ureido carbonyl group and the lysine C4 position, respectively. DMSO, DMSO solvent signal. C. Scaled-down version of part of the spectra given in (A) and (B) to show the difference in signal intensity of the ureido carbonyl group in $\mathrm{NaH}^{13} \mathrm{CO}_{3}$-labeled and unlabeled syringolin $A$, respectively.

that may be involved. To clarify these issues, more structural information about the large syringolin A synthetase and the SylC module must be obtained. The reconstitution of the enzymatic activities of the module(s) derived from the sylC gene in vitro will be challenging.

In addition to the syringolin family of compounds, a number of other natural cyclic peptides mostly isolated from cyanobacteria have been described in the literature that contain extracyclic ureido groups linking two different amino acids. These include anabaenopeptins from Anabaena, Oscillatoria, and Planktothrix species [13-16], ferintoic acids from Mycrocystis aeruginosa [17], pompanopeptins from Lyngbya confervoides [18], as well as mozamides and brunsvicamides, compounds of presumably cyanobacterial origin isolated from sponges $[19,20]$. Bicarbonate $/ \mathrm{CO}_{2}$ may also be the source of the ureido carbonyl group joining two extracyclic amino acids in the biosynthesis of these compounds, which, to our knowledge, has not been elucidated so far.

\section{Conclusion}

Our results show that the syl biosynthesis gene cluster was sufficient to direct the biosynthesis of bona fide syringolin A, including the enigmatic ureido group joining two amino acids. They reveal the source of the ureido carbonyl group to be bicarbonate/carbon dioxide, which we hypothesize is incorporated by carbamylation of valine mediated by the sylC gene product(s). A similar mechanism may also play a role in the biosynthesis of other ureido-group-containing NRPS products known largely from cyanobacteria.

\section{Methods}

\section{Construction and expression of pPL3syl}

Unless stated otherwise, standard protocols were used [29]. Genomic DNA from Pss B301D-R was isolated and 
$11 \mu \mathrm{g}$ were digested with the restriction enzymes AscI and NotI. AscI and NotI sites are both unique in the $s y l$ gene region (GenBank: AJ548826) located at position 2052 and 24124, respectively, within the ORFs flanking the sylA-sylE ORFs (3507-23596). A DNA gel blot was prepared with $1 \mu \mathrm{g}$ of the digested DNA and probed with a 32P-labeled sylA gene fragment PCR-amplified from genomic DNA with primers P1 (5'-ccatcgatggagtagagtgatggc) and P2 (5'-ggaattcttacaaaattcccatcttg). The rest of the digested DNA was separated on a $0.4 \%$ agarose gel and the DNA in the 20-23 kb size range was cut out, electrophoretically eluted into a dialysis bag (10 kDa cutoff), extracted first with 1 volume of phenol and then with 1 volume of phenol-chloroform-isoamylalcohol (25:24:1), precipitated with ethanol and finally taken up in TE (10 mM Tris-HCl, pH 8; 1 mM EDTA). Fragments were ligated into the HindIII/BamHI-cut broad host range cosmid vector pLAFR3 [21] using adaptors prepared by annealing the oligonucleotide 5'-cgcgccaagcttcca with 5'-agcttggaaagcttgg (AscI/HindIII adaptor) and 5'-ggccgctagtcaggag with 5'-gatcctcctgactagc (NotI/BamHI adaptor), respectively. Ligation products were packaged into lambda phage particles using the Gigapack III Gold Packaging Kit (Stratagene, La Jolla, California) and the library was plated out on E. coli XL1-Blue (Stratagene) and screened according to the instructions of the manufacturer using the ${ }^{32}$ P-labeled sylA gene fragment described above as a probe. Positive clones were isolated and confirmed to contain the complete syl gene cluster by PCR amplification and sequencing of the insert end fragments using primers 5'-ccggctacacgcattc (sylA end) and 5'-agcaacctggatgtacgg (sylE end) with the respective adaptor oligonucleotides (see above).

pPL3syl was transferred from XL1-Blue to Pseudomonas strains by triparental mating using the E. coli helper strain HB101 (pRK600) [30,31].

\section{Construction of the syl gene cluster deletion mutant syl}

Two fragments of $783 \mathrm{bp}$ and $655 \mathrm{bp}$ length flanking the syl gene cluster on the 5' and 3' side, respectively, were amplified by PCR from Pss B301D-R genomic DNA using the primer pairs P3 (5'-cgggatccaacctgaaatgggagagtc; base given in bold at position 2297 in GenBank:AJ548826) and P4 (5'-agcgcgaggactcaatgtgaaaacaacg; bold base at position 3072), and P5 (5'-tcacattgagtcctcgcgctggtaacc; bold base at position 23600) and P6 (5'-ttctgcagtcaagcctgacgaaaagc; bold base at position 24247), respectively. The two bands were isolated and joined by overlap extension PCR using primers P3 and P6 to yield a fragment flanked by BamHI and PstI restriction sites in which the syl gene cluster from position 3073-23599 (GenBank:AJ548826) was missing. The deletion is nearly identical with the one in the completely sequenced $P$. syringae pv. tomato DC3000 (GenBank:NC 004578.1), which does not contain a syl gene cluster. The fragment was cut with Bam HI and PstI and cloned into the respective restriction sites in the cloning box of the suicide vector pME3087 $\left(\mathrm{Tc}^{\mathrm{R}}\right.$, ColE1 replicon [32]). The recombinant plasmid was transformed into E. coli S17-1 (thi pro hsdR recA; chromosomal RP4 $\left(\mathrm{Tra}^{+} \mathrm{Tc}^{\mathrm{S}} \mathrm{Km}^{\mathrm{S}} \mathrm{Ap}^{\mathrm{S}}\right.$; transfer genepositive, tetracycline-sensitive, kanamycin-sensitive, ampicillin-sensitive) [33]) and mobilized into Pss B301D-R. Tetracycline-resistant colonies were grown in LB medium over night at $28^{\circ} \mathrm{C}$ on a rotary shaker $(220 \mathrm{rpm})$. For selection of tetracycline-sensitive colonies, the overnight cultures were diluted 100-fold with LB. After $2 \mathrm{~h}$ of growth, tetracycline was added $(20 \mu \mathrm{g} / \mathrm{ml}$ final concentration) and the cultures were grown for $1 \mathrm{~h}$, after which the bactericide carbenicillin ( $2 \mathrm{mg} / \mathrm{ml}$ final concentration) was added for $3 \mathrm{~h}$. The bacteria were then collected by centrifugation, and after washing them twice in LB, the selection procedure was repeated another 3 times. The cultures were then replica-plated on LB plates with and without tetracycline $(10 \mu \mathrm{g} / \mathrm{ml})$ and tetracycline-sensitive colonies were isolated (about 2-3\%). The desired deletion mutants were distinguished from wild-type revertants and verified by sequencing of a $1.7 \mathrm{~kb}$ DNA fragment amplified from genomic DNA by PCR using primers 5'-attactcgaccagttccg and 5'-ttacgcaatggtatgatgc which are located outside the fragment cloned into the suicide vector pME3087 at position 2113 and 24385 (GenBank: NC 007005.1), respectively.

\section{Construction of POEAC}

The sylA ORF was amplified from genomic DNA using the primers P7 (5'-ccatcgatggagtagagtgatggc; ClaI site in italics, translation initiation codon indicated in bold) and P8 (5'ggaattcttacaaaattcccatcttg; reverse primer; EcoRI site in italics, reverse stop codon in bold), digested with ClaI and EcoRI, and cloned into the respective polylinker sites of the pME6001 $\left(\mathrm{Gm}^{\mathrm{R}}\right)$ expression vector [34], thereby placing it under the control of the lac $Z$ promoter. The resulting plasmid was named pOEA. As it turned out that pOEA did not confer gentamycin resistance in $\mathrm{SRM}_{\mathrm{AF}}$ medium, pOEAC was used, a derivative of pME6014 $\left(\mathrm{Tet}^{\mathrm{R}}\right)$ [35], which, in addition to the lacZ::sylA chimeric gene, contained a sylC::lacZ reporter fusion gene in opposite orientation (the reporter gene is of no relevance in the present context). To construct pOEAC, the lacZ::sylA fusion gene was amplified from pOEA with primers P8 (see above) and P9 (5'-accgtccaacattaatgcagctgg; upstream of lac promoter; bold base complementary to position 987 of pBluescript vector (GenBank:X52329)) and joined with a sylC promoter fragment (position 5409-5649 of GenBank:AJ548826) that was amplified with primers P10 (5'ctgcattaatgttggacggtctgc; bold base at position 5409) and P11 (5'-aactgcagtcatgacggcctcggat; PstI site in italics, bold base at position 5649) by overlap extension PCR using primers $\mathrm{P} 8$ and P11. The resulting fragment was digested 
with EcoRI and PstI and cloned between the respective sites in the polylinker of pME6014.

\section{Bacterial infiltration of rice leaves and RNA gel blot analysis}

Bacterial strains were grown on a rotary shaker (220 rpm) over night at $28^{\circ} \mathrm{C}$ in LB containing, where appropriate, $10 \mu \mathrm{g} / \mathrm{ml}$ tetracycline. Bacteria were pelleted by centrifugation, washed twice in distilled water, resuspended in distilled water at an optical density at $600 \mathrm{~nm}\left(\mathrm{OD}_{600}\right)$ of 0.4 (approximately $10^{8} \mathrm{cfu}$ ), and infiltrated into first leaves of 14-day-old rice plants (Oryza sativa cv. Loto; supplied by Terreni alla Maggia, Ascona, Switzerland) as described previously [23]. RNA was extracted from infiltrated leaves $16 \mathrm{~h}$ after infiltration and subjected to gel blot analysis using a ${ }^{32}$ P-labeled Pir7b cDNA probe (GenBank:Z34270 [23]) according to standard procedures [29].

\section{HPLC analysis and mass spectrometry of syringolin A}

To analyze conditioned media with regard to syringolin A content, Pseudomonas strains were grown in $\mathrm{SRM}_{\mathrm{AF}}$ medium $[36,37]$ at $28^{\circ} \mathrm{C}$ for $60 \mathrm{~h}$ on a rotary shaker $(220$ $\mathrm{rpm})$. Bacteria were pelleted by centrifugation and the supernatant was sterile filtered $(0.22 \mu \mathrm{m}$ pore size). Twohundred-microliter aliquots were acidified with trifluoroacetic acid (TFA; $0.3 \%$ final concentration) and subjected to reverse-phase HPLC with a Reprosil 100-5 $\mathrm{C}_{18} 250 / 4.6$ column (Dr. Maisch GmbH, Ammerbuch-Entringen, Germany) on a Dionex UltiMate 3000 system (Dionex Corporation, Sunnyvale, CA). Elution was performed isocratically with $20 \%$ acetonitrile and $0.06 \%$ TFA in water at a flow rate of $1 \mathrm{ml} / \mathrm{min}$.

High-resolution electrospray mass spectra were recorded on a Bruker maXis QTOF-MS instrument (Bruker Daltonics GmbH, Bremen, Germany). The samples were dissolved in $\mathrm{MeOH}$ and analyzed via continuous flow injection at $3 \mu \mathrm{l} / \mathrm{min}$. The mass spectrometer was operated in positive ion mode with a capillary voltage of $4 \mathrm{kV}$, an endplate offset of $-500 \mathrm{~V}$, nebulizer pressure of $5.8 \mathrm{psig}$, and a drying gas flow rate of $4 \mathrm{l} / \mathrm{min}$ at $180^{\circ} \mathrm{C}$. The instrument was calibrated with a Fluka electrospray calibration solution (Sigma-Aldrich, Buchs, Switzerland) that was 100 times diluted with acetonitrile. The resolution was optimized at 30'000 FWHM in the active focus mode. The accuracy was better than $2 \mathrm{ppm}$ in a mass range between $m / z 118$ and 2721. All solvents used were purchased in best LC-MS qualities.

\section{${ }^{13}$ C-labeling and NMR Spectroscopy}

Pss B301D-R was transformed with pOEAC and grown in LB containing $10 \mu \mathrm{g} / \mathrm{ml}$ tetracycline on a shaker at $28^{\circ} \mathrm{C}$ until an $\mathrm{OD}_{600}$ of approximately 0.5 was reached. Bacteria were collected by centrifugation, washed twice with $\mathrm{SRM}_{\mathrm{AF}}$ medium, and taken up in $\mathrm{SRM}_{\mathrm{AF}}$ medium at an $\mathrm{OD}_{600}$ of 0.3 . Fifty-ml cultures were inoculated with 0.01 volume of the bacterial suspension and incubated at $28^{\circ} \mathrm{C}$ on a shaker (220 rpm). After $48 \mathrm{~h}, \mathrm{NaH}^{13} \mathrm{CO}_{3}(98 \%$; Sigma-Aldrich, Buchs, Switzerland) was added to a final concentration of $70 \mathrm{mM}$ and incubation was continued for $20 \mathrm{~h}$. Bacteria were pelleted and syringolin A was isolated from sterile-filtrated conditioned media as described [4].

${ }^{1} \mathrm{H}$ broadband decoupled ${ }^{13} \mathrm{C}$ NMR spectra were recorded at $25^{\circ} \mathrm{C}$ on a Bruker Avance III $600 \mathrm{MHz}$ spectrometer equipped with a cryogenic $5 \mathrm{~mm} \mathrm{CPDCH}$ probe head optimized for ${ }^{13} \mathrm{C}$ detection. Two samples were prepared by dissolving $200 \mu \mathrm{g}$ of labeled syringolin A in $130 \mu \mathrm{l}$ DMSO-d6 and $5 \mathrm{mg}$ of unlabeled syringolin A in $750 \mu \mathrm{l}$ DMSO-d6, respectively. The labeled sample was transferred to a $3 \mathrm{~mm}$ Shigemi tube, the unlabeled sample was transferred to a regular $5 \mathrm{~mm}$ NMR tube. The spectral width in both spectra was $248.5 \mathrm{ppm}$, the transmitter was set to $100 \mathrm{ppm}$. The excitation pulse angle was set to $45^{\circ}$. The acquisition time was $2.1 \mathrm{~s}$ with a waiting time of 0.3 $\mathrm{s}$ between two scans. Both spectra were ${ }^{1} \mathrm{H}$ broadband decoupled using the waltz16 composite-pulse decoupling scheme. The resulting fid consisted of 157890 total data points. For the unlabeled syringolin A sample 4000 scans were accumulated. For the labeled syringolin A sample 29605 scans were accumulated. Both spectra were zero filled to 131072 complex data points and processed using an exponential line broadening of $2 \mathrm{~Hz}$. The samples contained no internal chemical shift reference and the spectra were referenced to the solvent peak (39.5 ppm). By comparison with chemical shifts listed in [1] the signals at $157.8 \mathrm{ppm}$ and $132.8 \mathrm{ppm}$ were assigned to the ureido $\mathrm{CO}$ group and the olefinic $\mathrm{C}$ at position 4 in the 3,4-dehydrolysine moiety, respectively.

\section{Authors' contributions}

CR carried out the majority of experiments. The pPL3syl cosmid and the $\Delta$ syl deletion mutant were constructed by MT and MM, respectively. Mass spectrometry and NMR spectroscopy were performed and analyzed by LB and MOE, respectively. BS performed RNA gel blot analyses in the rice infiltration experiments. $\mathrm{RD}, \mathrm{CR}$, and $\mathrm{BS}$ designed experiments and RD wrote a draft manuscript. All authors provided critical inputs to the manuscript.

\section{Acknowledgements}

We thank Zsuzsa Hasenkamp for expert technical assistance, and Enrico Martinoia, Stefan Hörtensteiner, Markus Kaiser, and André Bachmann for discussions and helpful comments on the manuscript. Financial support by the Swiss National Science Foundation (grant 3100A0-II5970 to RD) is acknowledged.

\section{References}

I. Wäspi U, Blanc D, Winkler T, Ruedi P, Dudler R: Syringolin, a novel peptide elicitor from Pseudomonas syringae pv. syringae that induces resistance to Pyricularia oryzae in rice. Mol PlantMicrobe Interact 1998, I I(8):727-733. 
2. Wäspi U, Hassa P, Staempfli A, Molleyres L-P, Winkler T, Dudler R: Identification and structure of a family of syringolin variants: Unusual cyclic peptides from Pseudomonas syringae pv. syringae that elicit defense responses in rice. Microbiol Res 1999 , 154:I-5.

3. Michel K, Abderhalden O, Bruggmann R, Dudler R: Transcriptional changes in powdery mildew infected wheat and Arabidopsis leaves undergoing syringolin-triggered hypersensitive cell death at infection sites. Plant Mol Biol 2006, 62:56I-578.

4. Wäspi U, Schweizer P, Dudler R: Syringolin reprograms wheat to undergo hypersensitive cell death in a compatible interaction with powdery mildew. Plant Cell 200I, I3(I):|53-16I.

5. Groll M, Schellenberg B, Bachmann AS, Archer CR, Huber R, Powell TK, Lindow S, Kaiser M, Dudler R: A plant pathogen virulence factor inhibits the eukaryotic proteasome by a novel mechanism. Nature 2008, 452(7 I 88):755-758.

6. Clerc J, Groll M, Illich D], Bachmann AS, Huber R, Schellenberg B, Dudler R, Kaiser M: Synthetic and structural studies on syringolin $A$ and $B$ reveal critical determinants of selectivity and potency of proteasome inhibition. Proc Natl Acad Sci USA 2009, 106( 16):6507-65I2

7. von Döhren H, Dieckmann R, Pavela-Vrancic M: The nonribosomal code. Chem Biol 1999, 6( 10):R273-R279.

8. Marahiel MA, Stachelhaus T, Mootz HD: Modular peptide synthetases involved in nonribosomal peptide synthesis. Chem $\operatorname{Rev}$ 1997, 97(7):265I-2673

9. Finking R, Marahiel MA: Biosynthesis of nonribosomal peptides. Annu Rev Microbiol 2004, 58:453-488.

10. Amrein H, Makart S, Granado J, Shakya R, Schneider-Pokorny J, Dudler $R$ : Functional analysis of genes involved in the synthesis of syringolin A by Pseudomonas syringae pv. syringae B30ID-R. Mol Plant-Microbe Interact 2004, I 7(I):90-97.

II. Fischbach MA, Walsh CT: Assembly-line enzymology for polyketide and nonribosomal peptide antibiotics: Logic, machinery, and mechanisms. Chem Rev 2006, 106(8):3468-3496.

12. Hopwood DA: Genetic contributions to understanding polyketide synthases. Chem $\operatorname{Rev}$ 1997, 97(7):2465-2497.

13. Harada K, Fujii K, Shimada T, Suzuki M, Sano H, Adachi K, Carmichael WW: Two cyclic peptides, anabaenopeptins, a third group of bioactive compounds from the cyanobacterium Anabaena flos-aquae NRC-525-17. Tetrahedron Lett 1995, 36(9): I5 I - I5 |4.

14. Murakami M, Shin HJ, Matsuda H, Ishida K, Yamaguchi K: A cyclic peptide, anabaenopeptin B, from the cyanobacterium Oscillatoria agardhii. Phytochemistry 1997, 44(3):449-452.

15. Gesner-Apter S, Carmeli S: Three novel metabolites from a bloom of the cyanobacterium Microcystis sp. Tetrahedron 2008, 64(28):6628-6634.

16. Okumura HS, Philmus B, Portmann C, Hemscheidt TK: Homotyrosine-containing cyanopeptolins 880 and 960 and anabaenopeptins 908 and 915 from Planktothrix agardhii CYA 1 26/8. J Nat Prod 2009, 72(1): 172-176.

17. Williams DE, Craig M, Holmes CFB, Andersen RJ: Ferintoic acids A and $B$, new cyclic hexapeptides from the freshwater cyanobacterium Microcystis aeruginosa. I Nat Prod 1996, 59(6):570-575

18. Matthew S, Ross C, Paul VJ, Luesch H: Pompanopeptins A and B, new cyclic peptides from the marine cyanobacterium Lyngbya confervoides. Tetrahedron 2008, 64(1 8):408|-4089.

19. Schmidt EW, Harper MK, Faulkner DJ: Mozamides A and B, cyclic peptides from a theonellid sponge from Mozambique. J Nat Prod 1997, 60:779-782.

20. Muller D, Krick A, Kehraus S, Mehner C, Hart M, Kupper FC, Saxena $\mathrm{K}$, Prinz $\mathrm{H}$, Schwalbe $\mathrm{H}$, Janning $\mathrm{P}$, et al:: Brunsvicamides A-C: Sponge-related cyanobacterial peptides with Mycobacterium tuberculosis protein tyrosine phosphatase inhibitory activity. J Med Chem 2006, 49( I6):487|-4878.

21. Staskawicz B, Dahlbeck D, Keen N, Napoli C: Molecular characterization of cloned avirulence genes from race- 0 and race- $I$ of Pseudomonas syringae pv. glycinea. J Bacteriol 1987 , I 69( I 2):5789-5794

22. Wäspi U, Misteli B, Hasslacher M, Jandrositz A, Kohlwein SD, Schwab $H$, Dudler R: The defense-related rice gene Pir7b encodes an "alpha/beta hydrolase fold" protein exhibiting esterase activity towards naphthol AS-esters. Eur J Biochem 1998, 254:32-37.
23. Reimmann C, Hofmann C, Mauch F, Dudler R: Characterization of a rice gene induced by Pseudomonas syringae pv. syringae: Requirement for the bacterial lemA gene function. Physiol Mol Plant Pathol I 995, 46(I):7I-8I.

24. Senior E, Bull AT, Slater JH: Enzyme evolution in a microbial community growing on herbicide Dalapon. Nature 1976 , 263(5577):476-479.

25. Smith JA, Métraux JP: Pseudomonas syringae pathovar syringae induces systemic resistance to Pyricularia oryzae in rice. Physiol Mol Plant Pathol I99|, 39(6):45|-46I.

26. Kanehisa M, Araki M, Goto S, Hattori M, Hirakawa M, Itoh M, Katayama T, Kawashima S, Okuda S, Tokimatsu T, et al.: KEGG for linking genomes to life and the environment. Nucleic Acids Res 2008, 36:D480-D484

27. Golemi D, Maveyraud L, Vakulenko S, Samama JP, Mobashery S: Critical involvement of a carbamylated lysine in catalytic function of class D beta-lactamases. Proc Natl Acad Sci USA 200I, 98(25): | $4280-\mid 4285$

28. Maveyraud L, Golemi D, Kotra LP, Tranier S, Vakulenko S, Mobashery $S$, Samama JP: Insights into class $D$ beta-lactamases are revealed by the crystal structure of the OXAIO enzyme from Pseudomonas aeruginosa. Structure 2000, 8(12): 1289-1298.

29. Ausubel FM, Brent R, Kingston RE, Moore DD, Smith JA, Seidman JG, Struhl K: Current protocols in molecular biology. New York: Wiley and Sons; 1987.

30. Finan TM, Kunkel B, Devos GF, Signer ER: 2nd symbiotic megaplasmid in Rhizobium meliloti carrying exopolysaccharide and thiamin synthesis genes. J Bacteriol 1986, I67(I):66-72.

3I. Christensen BB, Sternberg C, Andersen JB, Palmer RJ, Nielsen AT, Givskov M, Molin S: Molecular tools for the study of biofilm physiology. In Methods Enzymol San Diego: Academic Press; 1999:20-42.

32. Voisard C, Bull CT, Keel C, Laville J, Maurhofer M, Schnider U, Défago G, Haas D: Biocontrol of root diseases by Pseudomonas fluorescens CHAO: current concepts and experimental approaches. In Molecular ecology of rhizosphere microorganisms Edited by: F. OG, D. D, B B. Weinheim, Germany: VCH Publishers; 1994:67-89.

33. Simon $R$, Priefer $U$, Puhler A: A broad host range mobilization system for in vivo geneic engineering: transposon mutagenesis in Gram-negative bacteria. Bio-Technology 1983, I(9):784-79I.

34. Blumer C, Heeb S, Pessi G, Haas D: Global GacA-steered control of cyanide and exoprotease production in Pseudomonas fluorescens involves specific ribosome binding sites. Proc Natl Acad Sci USA 1999, 96(24): I4073-14078.

35. Schnider-Keel U, Seematter A, Maurhofer M, Blumer C, Duffy B, Gigot-Bonnefoy C, Reimmann C, Notz R, Defago G, Haas D, et al.: Autoinduction of 2,4-diacetylphloroglucinol biosynthesis in the biocontrol agent Pseudomonas fluorescens CHAO and repression by the bacterial metabolites salicylate and pyoluteorin. J Bacteriol 2000, I 82(5): $1215-1225$

36. Gross DC: Regulation of syringomycin synthesis in Pseudomonas syringae pv. syringae and defined conditions for its production. J Appl Bacteriol 1985, 58:167-174.

37. Mo $Y-Y$, Gross DC: Plant signal molecules activate the syrB gene, which is required for syringomycin production by Pseudomonas syringae pv. syringae. J Bacteriol I991, I73:5784-5792.

Publish with Bio Med Central and every scientist can read your work free of charge

"BioMed Central will be the most significant development for disseminating the results of biomedical research in our lifetime. "

Sir Paul Nurse, Cancer Research UK

Your research papers will be:

- available free of charge to the entire biomedical community

- peer reviewed and published immediately upon acceptance

- cited in PubMed and archived on PubMed Central

- yours - you keep the copyright 